\title{
The Calcimimetic Compound NPS R-568 Suppresses Parathyroid Cell Proliferation in Rats with Renal Insufficiency Control of Parathyroid Cell Growth Via a Calcium Receptor
}

Michihito Wada, Yoshihiro Furuya, Jun-ichi Sakiyama, Nami Kobayashi, Sonoe Miyata, Hiromi Ishii, and Nobuo Nagano Pharmaceutical Research Laboratory, Kirin Brewery Co., Ltd.,Takasaki-shi, Gunma 370-12, Japan

\begin{abstract}
Parathyroid (PT) cell hyperplasia is a common consequence of chronic renal insufficiency (CRI). NPS R-568 is a phenylalkylamine compound that acts as an agonist (calcimimetic) at the cell surface calcium receptor (CaR). To test the hypothesis that the CaR plays a role in PT hyperplasia in CRI, we tested the effect of NPS R-568 on PT cell proliferation in rats with renal insufficiency. Rats were subjected to 5/6 nephrectomy and then infused intraperitoneally with 5-bromodeoxyuridine (BrdU) to label S-phase cells. Two groups of nephrectomized rats received NPS R-568 by gavage twice daily for $4 \mathrm{~d}(1.5$ and $15 \mathrm{mg} / \mathrm{kg}$ body $\mathrm{wt})$. On day 5 , the number of BrdU-positive PT cells of vehicle-treated nephrectomized rats was 2.6-fold greater than that of the sham-operated control. Low and high doses of NPS R-568 reduced the number of BrdU-positive PT cells by 20 and 50\%, respectively. No changes in staining, however, were observed in ileal epithelial cells (CaR-negative) or in thyroidal C-cells (CaR-positive). Furthermore, the effect of NPS R-568 could not be explained by changes in serum $1,25(\mathrm{OH})_{2} \mathrm{D}_{3}$ or phosphorus. These results indicate that NPS R-568 suppresses PT cell proliferation in rats with renal insufficiency, and lend support to the linkage between the CaR and PT hyperplasia in CRI. (J. Clin. Invest. 1997.100:2977-2983.) Key words: calcium receptor - calcimimetics - parathyroid hormone $\cdot$ hyperplasia $\bullet$ chronic renal insufficiency
\end{abstract}

\section{Introduction}

Parathyroid $(\mathrm{PT})^{1}$ cells secrete $\mathrm{PTH}$ and play a central role in maintaining circulating levels of ionized calcium $\left(\mathrm{Ca}^{2+} ; 1\right)$.

\footnotetext{
Address correspondence to Nobuo Nagano, Ph.D., Pharmaceutical Research Laboratory, Kirin Brewery Co., Ltd., 3 Miyahara-cho, Takasaki-shi, Gunma 370-12, Japan. Phone: +81-273-46-9712; FAX: +81-273-47-5280; E-mail: n-nagano@kirin.co.jp

Received for publication 2 June 1997 and accepted in revised form 30 September 1997.
}

1. Abbreviations used in this paper: $\mathrm{BrdU}, 5$-bromodeoxyuridine; BUN, blood urea nitrogen; $\mathrm{Ca}^{2+}{ }_{0}$, extracellular $\mathrm{Ca}^{2+} ; \mathrm{CaR}$, calcium receptor; CRI, chronic renal insufficiency; GPCR, G-protein-coupled receptor; PBSM, skim milk/PBS; Pi, phosphorus; PT, parathyroid; PTH, parathyroid hormone.

J. Clin. Invest.

(C) The American Society for Clinical Investigation, Inc. 0021-9738/97/12/2977/07 \$2.00

Volume 100, Number 12, December 1997, 2977-2983

http://www.jci.org
Proliferation of PT cells governs the growth of the PT glands, and thereby exerts a long-term effect on the potential ability to synthesize PTH (2). In normal adults, very few PT cells proliferate, and growth of the PT glands is controlled at low levels (2). In contrast, abnormally increased PT cell proliferation (hyperplasia) is a common trait of hyperparathyroidism secondary to chronic renal insufficiency (CRI; 3, 4). Management of PT hyperplasia is of great clinical importance because malignancy of secondary hyperparathyroidism depends on the progression of PT hyperplasia (2-4). Although not precisely defined, the onset of PT hyperplasia due to CRI involves several factors such as 1,25-dihydroxyvitamin $\mathrm{D}_{3}\left(1,25(\mathrm{OH})_{2} \mathrm{D}_{3}\right)$ deficiency, phosphorus (Pi) retention, and hypocalcemia (5-7).

It has been proposed for a long time that hypocalcemia plays a pivotal role in secondary hyperparathyroidism development and PT cell hyperplasia (8). Extracellular $\mathrm{Ca}^{2+}\left(\mathrm{Ca}^{2+}{ }_{\mathrm{o}}\right)$ serves as a physiological regulator of PTH secretion $(9,10)$. PT cells sense small changes in extracellular $\mathrm{Ca}^{2+}\left(\mathrm{Ca}^{2+}{ }_{0}\right)$ by means of the cell-surface $\mathrm{Ca}^{2+}{ }_{0}$ receptor $(\mathrm{CaR})$ that recognizes $\mathrm{Ca}^{2+}{ }_{0}$ as its physiological ligand $(9,10)$. The $\mathrm{CaR}$ gene was cloned first from bovine PT cells, and sequence analysis demonstrated that the $\mathrm{CaR}$ is a G-protein-coupled receptor (GPCR) sharing limited homology with metabotropic glutamate receptors (11, 12). Two recent studies have demonstrated that CaR expression is downregulated at both mRNA and protein levels in the hyperplastic PT glands of patients with CRI $(13,14)$, suggesting linkage between this receptor and PT hyperplasia.

We hypothesized that the CaR might regulate PT cell proliferation and play an important role in PT hyperplasia observed in CRI. This hypothesis in turn indicates that $\mathrm{Ca}^{2+}$ o controls PT cell growth by CaR-mediated mechanisms. The effect of $\mathrm{Ca}^{2+}{ }_{\mathrm{o}}$ on PT cell growth, however, still remains controversial $(2,15)$. For example, the results from in vitro experiments studying the effects of low ambient concentrations of $\mathrm{Ca}^{2+}{ }_{\mathrm{o}}$ on PT cell growth are contradictory; some authors observed increased cell proliferation $(16,17)$ whereas others showed no effect on cell growth $(18,19)$. Likewise, in vivo there is no agreement as to whether PT cell growth is stimulated by hypocalcemia (6) or not (20). Furthermore, little is known about the effect of hypercalcemia on PT cell growth because it is difficult to produce hypercalcemia without affecting general cellular functions for a long enough time to evaluate cell proliferation $(15,21)$.

Synthetic compounds referred to as calcimimetics, acting as specific agonists at the CaR, have been developed $(22,23)$. Upon binding to the $\mathrm{CaR}$, calcimimetics enhance the sensitivity of the $\mathrm{CaR}$ to $\mathrm{Ca}^{2+}{ }_{\mathrm{o}}$ in an allosteric fashion and exert a suppressive effect on PTH secretion $(22,23)$. Of these calcimimetics, NPS R-568, a phenylalkylamine derivative of the most potent calcimimetics, has been subjected to clinical trials, and has been shown to produce a dose-dependent decrease in the circulating levels of PTH in both normal women (24) and patients with primary hyperparathyroidism (25). In this study, to 
test the hypothesis that the CaR plays a role in PT hyperplasia development, we evaluated the effect of NPS R-568 on PT cell growth in rats with renal insufficiency. Our results demonstrate that oral administration of NPS R-568 clearly inhibit PT cell proliferation, which was markedly accelerated in rats with renal insufficiency.

\section{Methods}

Chemicals. NPS R-568, $N$-(3-[2-chlorophenyl]-propyl)-R- $\alpha$-methyl3-methoxybenzylamine $\mathrm{HCl}$, referred to as KRN568 in Japan, was synthesized by OREAD Laboratories, Inc. (Lawrence, KS). Cyclodextrin (2-hydroxypropyl- $\beta$-cyclodextrin) was obtained from Research Biochemicals International (Natick, MA) and 5-bromo-2'deoxyuridine (BrdU) was from Sigma Chemical Co. (St. Louis, MO).

Experimental protocols. 10-wk-old Male Sprague-Dawley rats weighing 310-350 g were purchased from Charles River Japan (Tokyo, Japan) and fed a diet containing $1.1 \% \mathrm{P}, 1.2 \% \mathrm{Ca}, 25 \%$ protein, and $250 \mathrm{IU} / 100 \mathrm{~g}$ vitamin $\mathrm{D}_{3}$ (CLEA Japan, Tokyo, Japan). Rats were allowed free access to food and water. After acclimatization for $10 \mathrm{~d}$, three groups of rats were subjected to 5/6 nephrectomy under ether anesthesia by removing the right kidney and ligating branches of the left renal artery in a one-step procedure. Another group of rats underwent sham operation and served as a normal control. Each group was assigned six animals. Two groups of 5/6 nephrectomized rats received NPS R-568 by gavage twice daily for $4 \mathrm{~d}$ at doses of 1.5 and $15 \mathrm{mg}$ free base/kg body wt, respectively. One group of 5/6 nephrectomized rats and the sham-operated rats were given vehicle (a $10 \%$ aqueous solution of cyclodextrin). Administration was carried out at 1600-1700 and 2100-2200 $\mathrm{h}$ on the day of the operation, and at 0900-1000 $\mathrm{h}$ and 1800-1900 $\mathrm{h}$ on three subsequent days. $4 \mathrm{~d}$ after $5 / 6$ nephrectomy, animals were killed by aortic puncture under ether anesthesia and subjected to necropsy (see Fig. 1). At the time of necropsy, one animal treated with NPS R-568 at $1.5 \mathrm{mg} / \mathrm{kg}$ body wt was excluded from the study because of severe uremia.

Infusion of BrdU. To evaluate cell proliferation, animals were intraperitoneally infused with BrdU, a thymidine analog, for $4 \mathrm{~d}$ (see Fig. 1). Alzet osmotic pumps with a speed of $10.51 \pm 0.48$ (SD) $\mu \mathrm{l} / \mathrm{h}$ (Model 2ML1; Alza Corp., Palo Alto, CA) were filled with $25 \mathrm{mg} / \mathrm{ml}$ BrdU in PBS, incubated in PBS at $37^{\circ} \mathrm{C}$ overnight for conditioning, and implanted in the abdominal cavity at the time of $5 / 6$ nephrectomy or the sham operation. BrdU was released at a dose of $\sim 6 \mathrm{mg} / \mathrm{animal} / \mathrm{d}$.

Serum biochemistry. Blood was collected via the tail artery to evaluate $\mathrm{PTH}, \mathrm{Ca}$, and Pi during the course of the experiment, and via the abdominal artery to evaluate creatinine, blood urea nitrogen $(\mathrm{BUN})$, electrolytes, and $1,25(\mathrm{OH})_{2} \mathrm{D}_{3}$ at necropsy. Serum was separated and stored at $-80^{\circ} \mathrm{C}$. Serum creatinine, BUN, Ca, and Pi were measured using standard colorimetric methods with a spectrophotometer (U-2000; Hitachi Ltd.,Tokyo, Japan). Serum $\mathrm{Na}^{+}, \mathrm{K}^{+}$, and $\mathrm{Cl}^{-}$were determined with an automated electrolyte analyzer (PVAaII; A\&T Corp., Tokyo, Japan). Serum immunoreactive PTH was examined using a rat IRMA kit (Immutopics, Inc., San Clemente, CA), and serum $1,25(\mathrm{OH})_{2} \mathrm{D}_{3}$ was quantified using a calf mammary gland radioreceptor-assay kit (Yamasa, Inc., Tokyo, Japan).

Tissue processing. Tissues were necropsied and fixed for $4 \mathrm{~d}$ at $4^{\circ} \mathrm{C}$ with $10 \%$ phosphate-buffered formalin. After dehydration by passage through an ethanol/xylene series, tissues were embedded in TissuePrep (Fisher Scientific Co., Fairlawn, NJ). The thyroid-parathyroid tissue together with a portion of the adjoining trachea was cut into $3-\mu \mathrm{m}$-thick sections in the sagittal plane; sections were taken from the most central levels of each gland at a distance of $\sim 30 \mu \mathrm{m}$. The ileum was cut into $3-\mu \mathrm{m}$-thick cross-sections.

Immunohistochemistry. To identify proliferating cells, BrdU-incorporated cells were detected using a BrdU immunostaining kit (Zymed Labs, Inc., S. San Francisco, CA). After sequential dewaxing and rehydration, slides were incubated with $3 \%$ hydrogen peroxide/ methanol to block endogenous peroxidase for $10 \mathrm{~min}$. Slides were digested with $0.1 \%$ trypsin for $20 \mathrm{~min}$ at $37^{\circ} \mathrm{C}$, rinsed with distilled water three times for 15 min each time, and incubated with Zymed acid solution to denature DNA for $30 \mathrm{~min}$ at room temperature. Slides were then reacted with anti-BrdU monoclonal antibody at $4^{\circ} \mathrm{C}$ overnight. The bound primary antibody was detected by the streptavidinbiotin-immunoperoxidase method. Slides were developed with 3.3'diaminobenzidine and counterstained with hematoxylin. BrdU was identified as brown staining in the nucleus.

To identify proliferating $\mathrm{C}$ cells, double immunostaining for calcitonin and BrdU was performed. After sequential dewaxing and rehydration, slides were incubated for $30 \mathrm{~min}$ at $4^{\circ} \mathrm{C}$ with $4 \%$ defatted skim milk/PBS (PBSM) to block nonspecific binding of the primary antibody. Slides were reacted with the anticalcitonin polyclonal antibody (L1804; Dako Corp., Carpinteria, CA) in PBSM (1:200 dilution) for $16-18 \mathrm{~h}$ at $4^{\circ} \mathrm{C}$. The bound primary antibody was detected by the avidin-biotin complex immunoalkaline phosphatase method (Vector Laboratories, Inc., Burlingame, CA). Slides were developed using the Vector-Red system followed by Zymed BrdU-staining as described above. Calcitonin was detected as red staining in the cytoplasm, and BrdU appeared as brown staining in the nucleus. The specificity for calcitonin was verified by the lack of cellular staining when the primary antibody was replaced with the pre-immune rabbit serum (L1804; Dako Corp.).

Immunostaining for cyclin D1 was performed using the polyclonal antibodies H-295 and C-20 (Santa Cruz Biotechnology, Santa Cruz, CA). Before immunostaining, sections were sequentially permeabilized with 0.2 and $0.5 \%$ Triton X-100/PBS for 15 min each time. Slides were incubated with PBSM and reacted with the anti-cyclin D1 antibodies in PBSM (1:200 dilution for H-295, and 1:50 dilution for C-20) at $4^{\circ} \mathrm{C}$ overnight. The bound primary antibody was detected by the avidin-biotin complex immunoalkaline phosphatase method (Vector Laboratories, Inc.). Slides were developed using the Vector-Red system. The specificity for cyclin D1 was verified by preabsorpting the primary antibodies with 10 -fold excess human cyclin D $1^{1-295}$ for H-295, and mouse cyclin D $1^{276-295}$ for C-20 (each peptide purchased from Santa Cruz Biotechnology), which resulted in markedly reduced staining.

Detection of apoptosis. To identify apoptosis, nuclear DNA fragmentation was detected in situ using the ApopTag system (Oncor Inc., Gaithersburg, MD). Slides were digested with $20 \mu \mathrm{g} / \mathrm{ml}$ proteinase K (Boehringer Mannheim, Mannheim, Germany) in PBS at room temperature for $15 \mathrm{~min}$ and incubated with $3 \%$ hydrogen peroxide/ methanol to block endogenous peroxidase for $5 \mathrm{~min}$. Slides were reacted for $1 \mathrm{~h}$ at $37^{\circ} \mathrm{C}$ with terminal deoxynucleotidyl transferase (TdT) to label exposed 3 '-OH DNA ends with digoxigenin-tagged nucleotide (26). Digoxigenin-labeled DNA was detected by the immunoperoxidase method. Slides were developed with $3.3^{\prime}$-diaminobenzidine, and the nuclei of apoptotic cells were stained brown. The specificity for apoptosis was verified by negative staining when distilled water was substituted for TdT.

Cell counting and morphometry. The number of BrdU-positive cells was counted at $400 \times$ and expressed as a percentage per total cell number. The coefficient of variation between counts of the same gland was $8.3 \%$ for PT cells and $14.5 \%$ for thyroid C cells. Unbiased cell volume (volume-weighted cell volume) was measured according to Gundersen (27). Micrographs at 1,000× (oil immersion) were taken randomly and coded blind. A $7 \times 7$ lattice-point grid was overlain on each micrograph $(10 \times 10 \mu \mathrm{m}$ lattice on the micrograph $)$, and cells hit by the lattice points were chosen to measure the vertical intercepts $\left(l_{0}\right)$. The volume-weighted volume of the cells was calculated by $(\pi / 3)$ $1_{0}{ }^{3}$. The coefficient of variation between micrographs of the same gland was $13.0 \%$.

Statistics. Data are expressed as means \pm SEM. The statistical significance of differences between groups was determined using Dunnett's multiple comparison test, and the correlation coefficients between pairs of parameters were obtained using Pearson's correlation analysis. $P<0.05$ was taken to indicate statistical significance. 


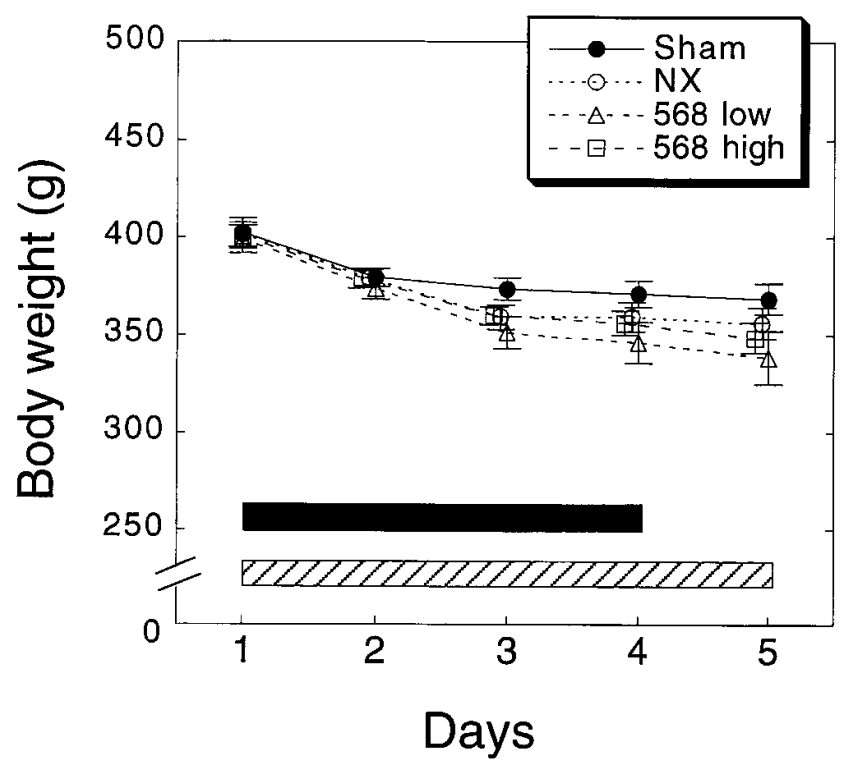

Figure 1. Effects of NPS R-568 on body weight changes. Rats were subjected to 5/6 nephrectomy or sham operation on day 1 , and to necropsy on day 5 . The sham-operated (Sham) and nephrectomized controls $(N X)$ were treated with vehicle, and two groups of nephrectomized animals received NPS R-568 twice daily at 1.5 and $15 \mathrm{mg} / \mathrm{kg}$ body wt (568 low and 568 high, respectively). NPS R-568 was administered p.o. for $4 \mathrm{~d}$ (solid bar), and BrdU was infused intraperitoneally throughout the experiment (hatched bar). Results are expressed as means \pm SEM (five or six animals per group as shown in Table I).

\section{Results}

There were no significant differences in body weight between NPS R-568-treated animals and the vehicle-treated controls during the course of the experiment (Fig. 1). Uremia was produced by $5 / 6$ nephrectomy, as evidenced by increased serum creatinine and BUN levels, while these indices were not significantly affected by treatment with NPS R-568 (Table I). In the $5 / 6$ nephrectomized animals, the circulating levels of 1,25 $(\mathrm{OH})_{2} \mathrm{D}_{3}$ were $50 \%$ lower than those in the sham-operated controls. NPS R-568 did not significantly change serum 1,25 $(\mathrm{OH})_{2} \mathrm{D}_{3}$ levels (Table I). In contrast, serum PTH levels were reduced by NPS R-568 in a dose-dependent manner (Fig. $2 \mathrm{~A}$ ). The reduction in serum PTH levels was associated with de-
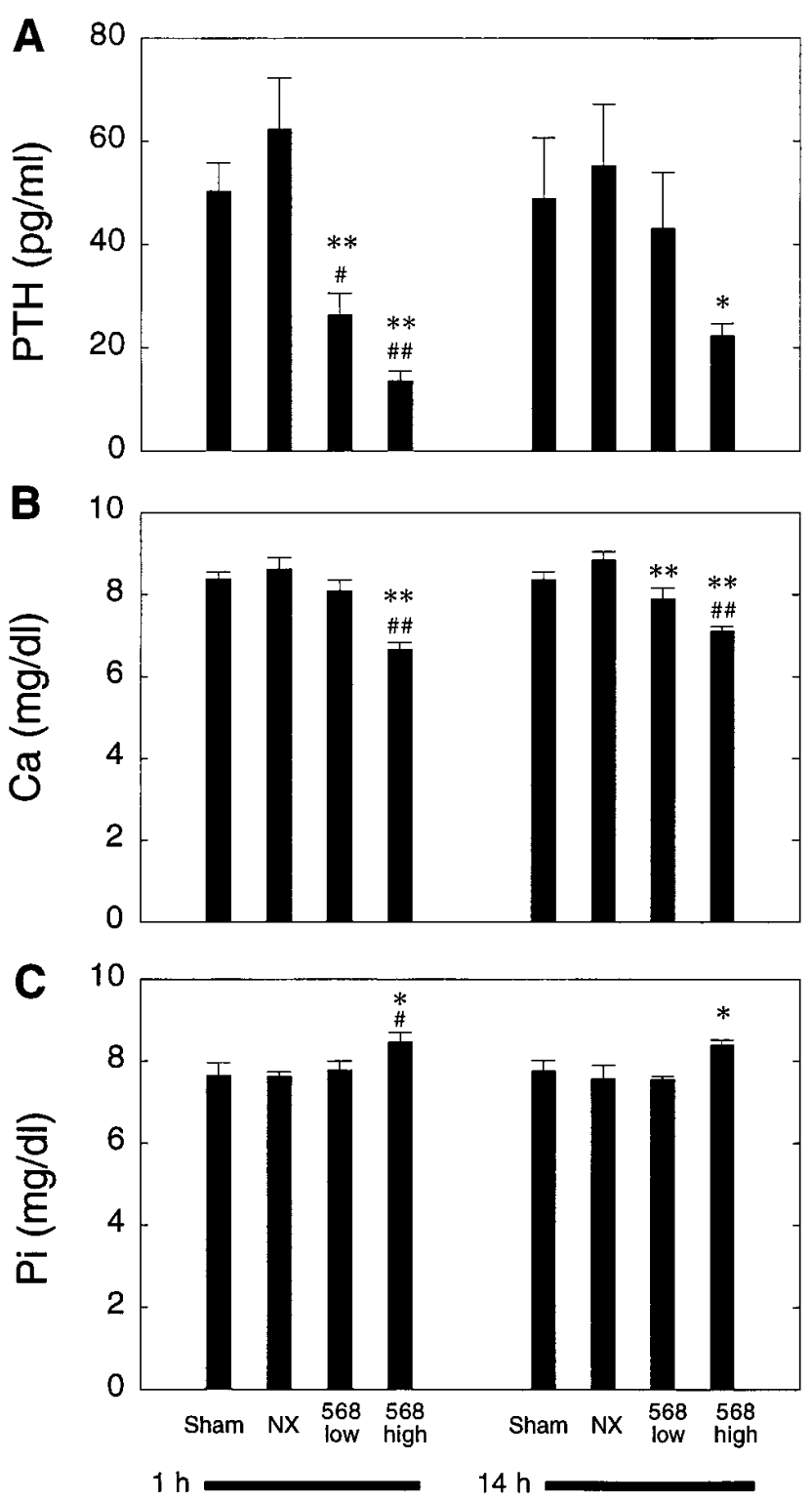

Figure 2. Serum PTH levels reduced by NPS R-568 $(A)$ associated with decreased serum Ca levels $(B)$ and increased Pi levels $(C)$. Blood was collected sequentially 1 and $14 \mathrm{~h}$ after the last gavage of NPS R-568. Results are shown as means \pm SEM. ${ }^{\#} P<0.05,{ }^{\#} P<0.01$ vs. the Sham control; and $* P<0.05, * * P<0.01$ vs. NX controls at each time point.

Table I. Effects of NPS R-568 on Serum Biochemical Indices in 5/6 Nephrectomized Rats

\begin{tabular}{|c|c|c|c|c|c|c|c|}
\hline & $n$ & Creatinine & BUN & $\mathrm{Na}^{+}$ & $\mathrm{K}^{+}$ & $\mathrm{Cl}^{-}$ & $1,25(\mathrm{OH})_{2} \mathrm{D}_{3}$ \\
\hline & & $m g / d l$ & $m g / d l$ & $m E q /$ liter & $m E q /$ liter & $m E q /$ liter & $\mathrm{pg} / \mathrm{ml}$ \\
\hline Sham & 6 & $0.29 \pm 0.01$ & $15.9 \pm 0.9$ & $147.7 \pm 0.6$ & $4.77 \pm 0.21$ & $109 \pm 0.4$ & $54.3 \pm 12.8$ \\
\hline NX & 6 & $0.91 \pm 0.06^{\ddagger}$ & $40.3 \pm 2.9^{\ddagger}$ & $147.0 \pm 0.9$ & $5.25 \pm 0.19$ & $105 \pm 0.9 *$ & $25.9 \pm 2.6^{*}$ \\
\hline 568 low & 5 & $1.07 \pm 0.08^{\ddagger}$ & $53.5 \pm 6.5^{\ddagger}$ & $148.4 \pm 2.3$ & $5.51 \pm 0.30$ & $105 \pm 1.7 *$ & $20.9 \pm 3.3^{*}$ \\
\hline 568 high & 6 & $1.16 \pm 0.12^{\ddagger}$ & $49.3 \pm 5.5^{\ddagger}$ & $147.1 \pm 0.6$ & $5.35 \pm 0.32$ & $104 \pm 1.1^{\ddagger}$ & $31.1 \pm 3.9$ \\
\hline
\end{tabular}

Sham, sham-operated control; NX, 5/6 nephrectomized controls treated with vehicle; 568 low, 5/6 nephrectomized animals treated with NPS R-568 at $1.5 \mathrm{mg} / \mathrm{kg}$ body wt; 568 high, $5 / 6$ nephrectomized animals treated with NPS R-568 at $15 \mathrm{mg} / \mathrm{kg}$ body wt. $* P<0.05 ;{ }^{*} P<0.01 \mathrm{vs}$. the sham control. 

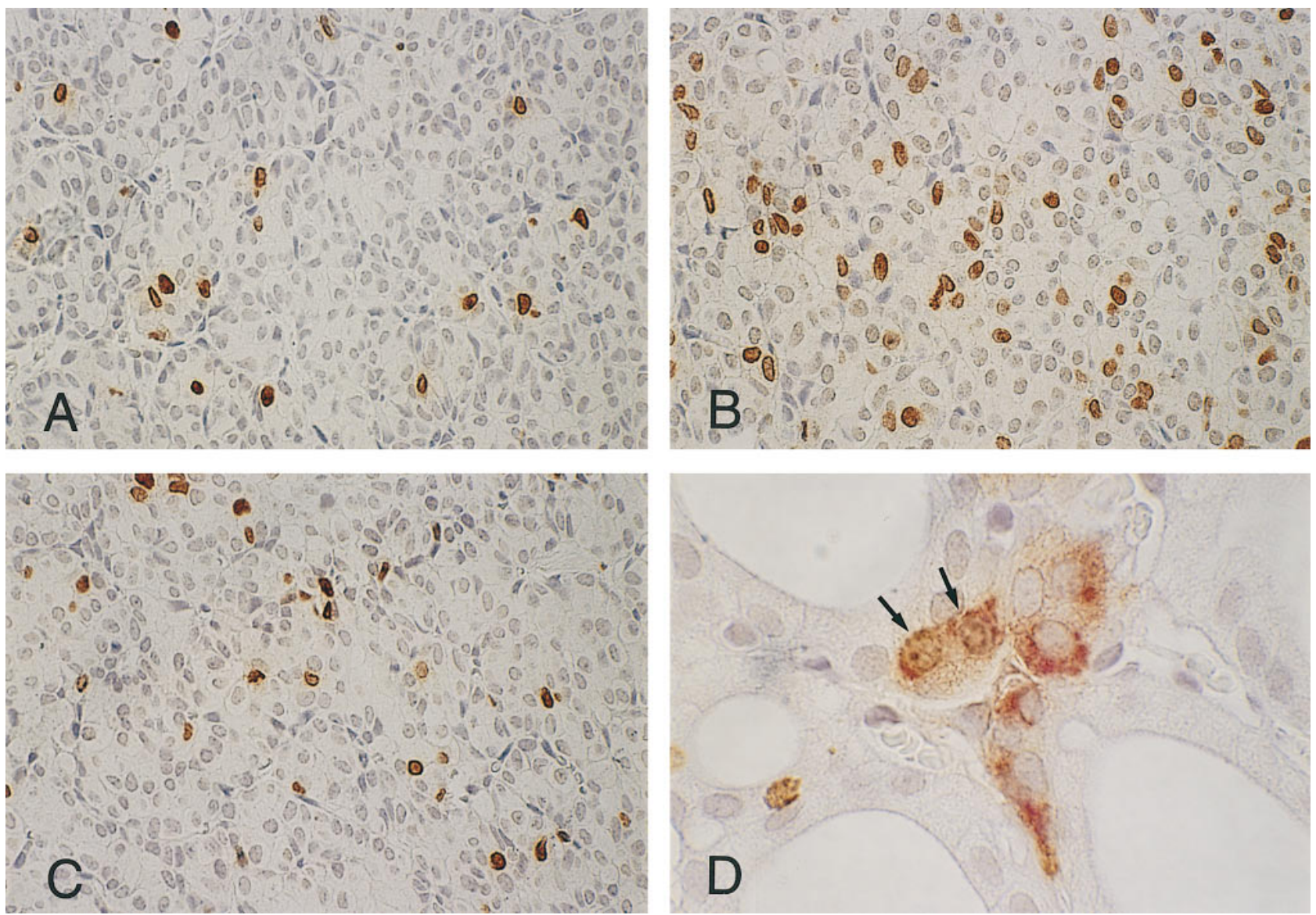

Figure 3. Immunohistochemistry for BrdU. The parathyroid glands of Sham $(A)$, NX $(B)$, and NPS R-568 at a high dose $(C)$ and the thyroid gland of NPS R-568 at a low dose $(D)$. BrdU is seen as brown staining in the nucleus, and $(D)$ calcitonin appears as red staining in the cytoplasm. Arrows indicate double-positive cells. $400 \times$, original $(A-C)$ and $1,000 \times(D)$.

creased serum $\mathrm{Ca}$ and increased serum Pi levels (Fig. 2). Administration of NPS R-568, however, did not affect circulating levels of the electrolytes $\mathrm{Na}^{+}, \mathrm{K}^{+}$, and $\mathrm{Cl}^{-}$(Table I).

$4 \mathrm{~d}$ after 5/6 nephrectomy, the number of BrdU-positive PT cells in the vehicle-treated 5/6 nephrectomized animals was 2.6-fold greater than that of the sham-operated control (Figs. 3 and 4). NPS R-568 clearly reduced the number of BrdU-positive PT cells by $20 \%$ at a low dose $(1.5 \mathrm{mg} / \mathrm{kg}$ body $\mathrm{wt})$, and by $50 \%$ at a high dose $(15 \mathrm{mg} / \mathrm{kg}$ body $\mathrm{wt})$, indicating an antiproliferative effect on PT cells (Figs. 3 and 4). In contrast, NPS R-568 did not change the number of BrdU-positive cells in other tissues. In the ileum, almost $100 \%$ of epithelial cells were BrdU-positive, and were not affected by NPS R-568 treatment (data not shown). In addition, double immunostaining for calcitonin and BrdU (Fig. 3 D) showed that the number of BrdUpositive C cells was not affected by 5/6 nephrectomy or NPS R-568 treatment (Fig. 4). This result was further confirmed by plotting the number of BrdU-positive cells against serum creatinine levels. In PT cells, but not in C cells, the number of BrdUpositive cells was correlated with serum creatinine levels $(r=$ $0.879, P<0.01$ for pooled normal and uremic controls), while this relationship was abolished by high dose of NPS R-568 (Fig. 5).

It was reported that cyclin D1 might serve as a regulator of $\mathrm{Ca}^{2+}{ }_{\mathrm{o}}$-dependent PT cell proliferation (28). To test this hy-

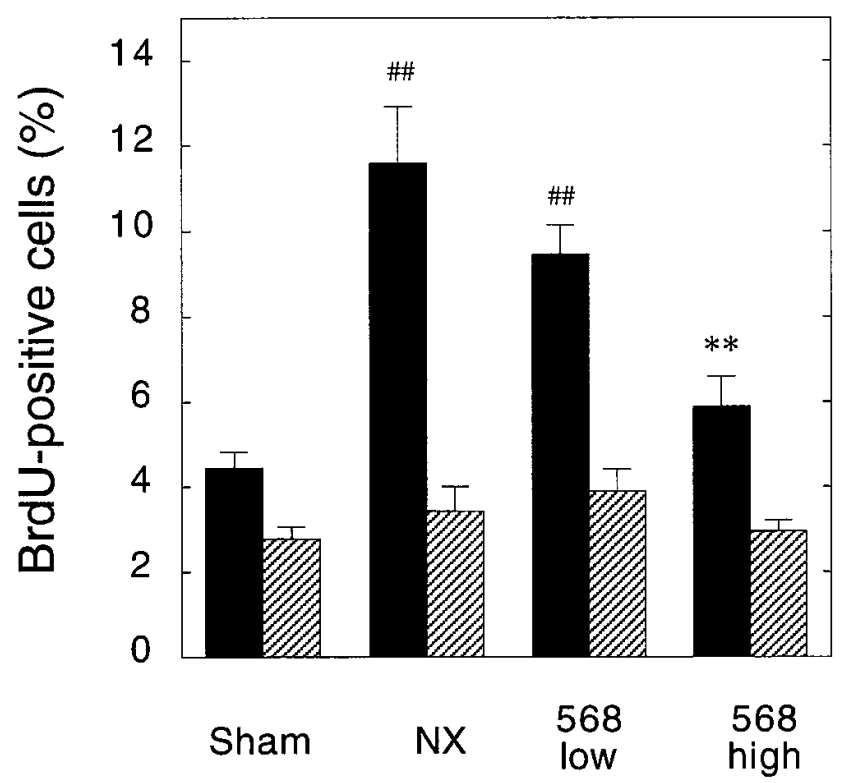

Figure 4. Effects of NPS R-568 on the proliferation of parathyroid and thyroid $C$ cells. Results are shown as mean \pm SEM. ${ }^{\# \#} P<0.01$ vs. the Sham control, and $* * P<0.01$ vs. NX controls. Black bars, parathyroid cells; hatched bars, thyroid $\mathrm{C}$ cells. 

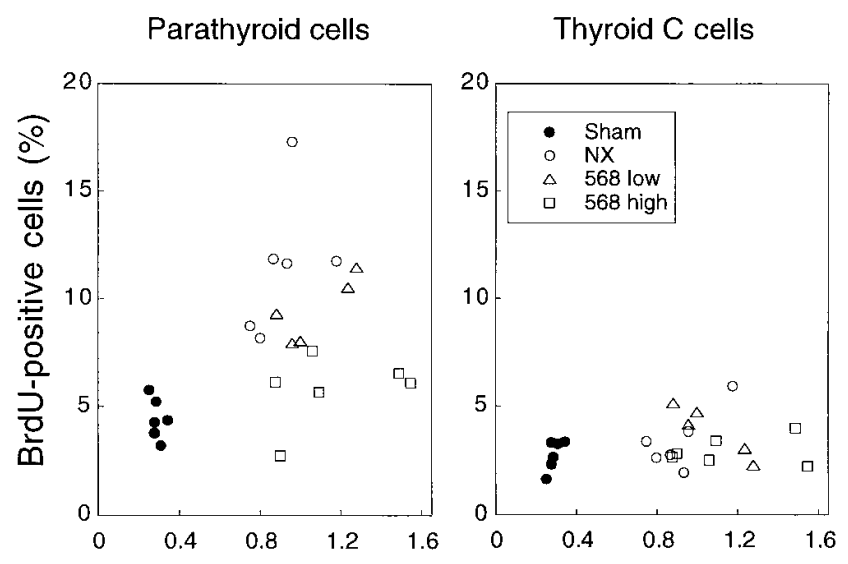

\section{Serum creatinine $(\mathrm{mg} / \mathrm{dl})$}

Figure 5. The number of BrdU-positive cells plotted against serum creatinine levels. Note that the effect of NPS R-568 on parathyroid cells was independent of serum creatinine levels. Each point represents the data of each animal.

pothesis, we next evaluated cyclin D1 expression by immunostaining using two independent anti-cyclin D1 antibodies (H-295 and C-20). In the cytoplasm, the staining intensity for cyclin D1 in PT cells was stronger than that in thyroid follicular cells, but was not apparently changed by $5 / 6$ nephrectomy or NPS R-568 treatment; the two antibodies gave similar results in the thyroid-parathyroid tissue (data not shown). It should be noted, however, that the cell volume of PT cells was increased by $37 \%$ after $5 / 6$ nephrectomy, i.e., hypertrophy was induced, whereas NPS R-568 reduced PT cell volume in a dose-dependent manner (Fig. 6). Hence, the total amount of cyclin D1 ex-

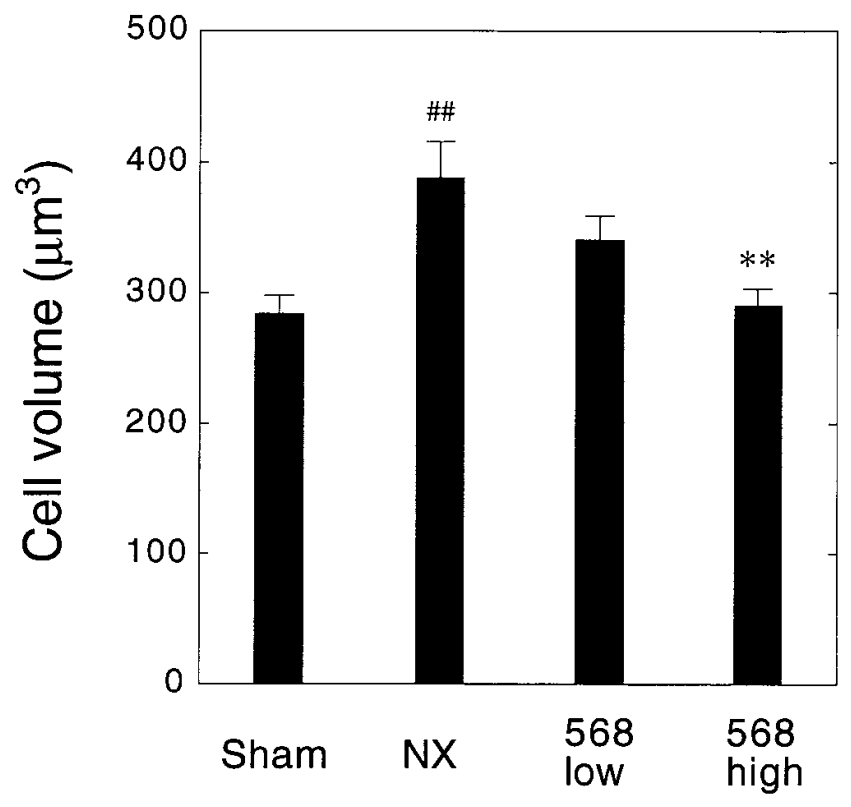

Figure 6. Effect of NPS R-568 on parathyroid cell volume. Note that hypertrophy was induced by $5 / 6$ nephrectomy, and it was reversed by treatment with NPS R-568. Results are shown as means \pm SEM. ${ }^{\# \#} P<$ 0.01 vs. the Sham control, and $* * P<0.01$ vs. NX controls
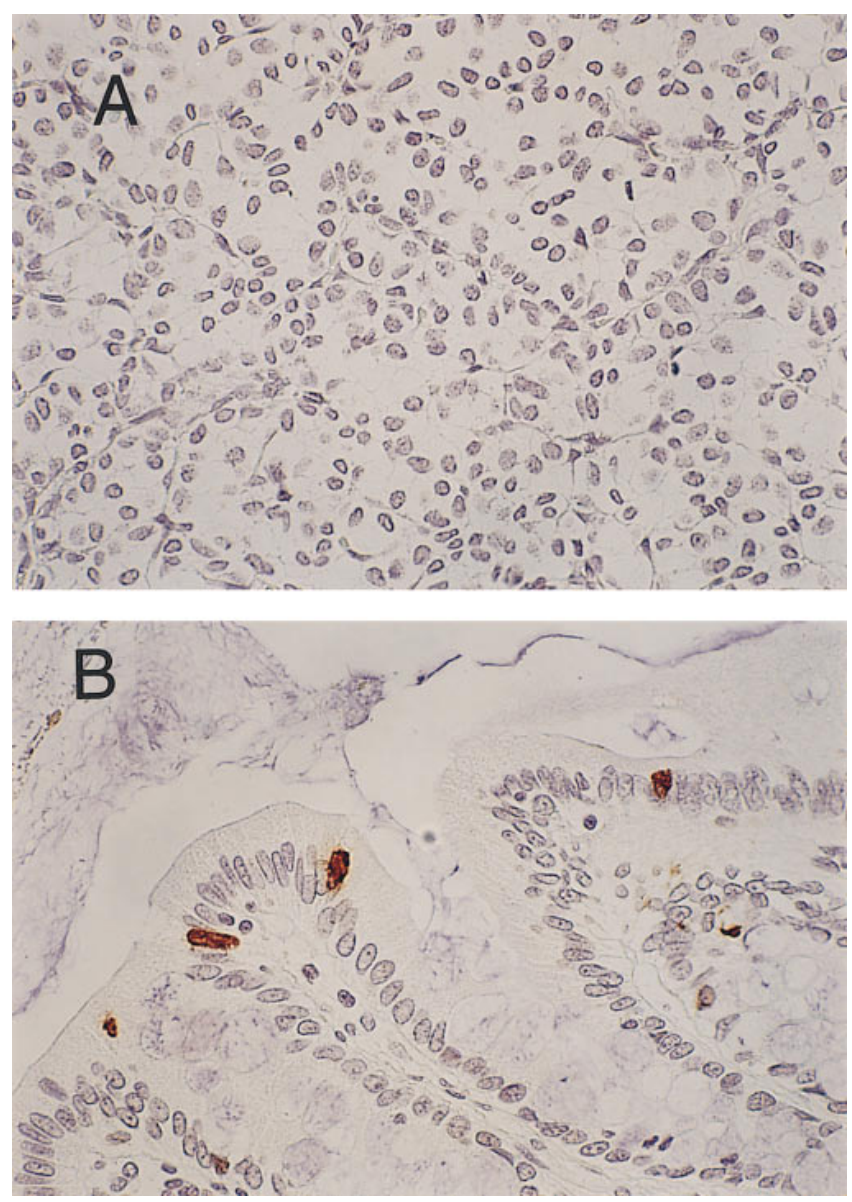

Figure 7. Detection of nuclear DNA fragmentation, a hallmark of apoptosis, in situ. The parathyroid gland of an animal treated with NPS R-568 at a high dose $(A)$, and the ileum of the same animal $(B)$. $400 \times$, original.

pressed in PT cells might be affected by the changes in cell volume.

The speed of cell proliferation is generally balanced by the rate of cell death. Thus, we examined nuclear DNA fragmentation, a hallmark of apoptosis, in situ. We detected no apoptosis, however, in the PT glands of any sham-operated, 5/6 nephrectomized, or NPS R-568-treated animals, even at the high dose of $15 \mathrm{mg} / \mathrm{kg}$ body wt (Fig. $7 A$ ). On the other hand, apoptosis was observed in epithelial cells in the ileum as reported previously (Fig. $7 B ; 26$ ).

\section{Discussion}

There has been as yet no consensus as to whether PT cell proliferation is regulated by $\mathrm{Ca}^{2+}{ }_{0}(2,15)$. Previous studies, indicating that PT hyperplasia begins within 48 to $72 \mathrm{~h}$ in nephrectomized rats (29-31), prompted us to perform our experiments within $5 \mathrm{~d}$ after $5 / 6$ nephrectomy. The main finding of this study was that the calcimimetic compound NPS R-568, which acts as an agonist at the CaR $(22,23)$, inhibited PT cell proliferation in rats with renal insufficiency. The animal model used here is an approximation of human polyclonal PT cell expansion in CRI $(2,3)$. Our results lend support to the linkage between the $\mathrm{CaR}$ and development of PT hyperplasia in CRI. 
Several lines of evidence support the hypothesis that the $\mathrm{CaR}$ plays a critical role in regulating PT cell proliferation. First, loss-of-function mutations in the $\mathrm{CaR}$, which cause the diseases familial benign hypocalciuric hypercalcemia and neonatal severe hyperparathyroidism, are generally associated with PT hyperplasia (32). Second, this observation was confirmed by the PT hyperplasia seen in mice nullizygous for the $\mathrm{CaR}$, a genetic model for neonatal severe hyperparathyroidism (33). Third, CaR expression is downregulated at both mRNA and protein levels in the hyperplastic PT glands in patients with CRI $(13,14)$, suggesting a role for this receptor in the development of PT hyperplasia.

Consistent with these findings, we have demonstrated that the calcimimetic compound NPS R-568 that specifically acts on the $\mathrm{CaR}$ can inhibit PT cell proliferation in rats with renal insufficiency. The possibility that the antiproliferative action was mediated by alleviation of $1,25(\mathrm{OH})_{2} \mathrm{D}_{3}$ deficiency or Pi retention was excluded since $1,25(\mathrm{OH})_{2} \mathrm{D}_{3}$ levels were not affected by treatment with NPS R-568, and the Pi level of NPS R-568treated animals was rather greater than that of the vehicletreated controls. The increase in Pi level is thought to be ascribed to reduced PTH levels (1). Moreover, the possibility that the action was mediated by renal functions was also ruled out because the antiproliferative effect of NPS R-568 was independent of serum creatinine levels. In contrast, PTH secretion and PT hypertrophy were clearly inhibited by NPS R-568. Therefore, we concluded that NPS R-568 principally, if not solely, exerted its suppressive effect on PT cells by directly acting on the $\mathrm{CaR}$.

This conclusion was further supported by the tissue-specific antiproliferative effect of NPS R-568. Intestinal epithelial cells (CaR-negative) and thyroidal C-cells (CaR-positive) were not affected, suggesting that NPS R-568 has no general cytotoxic action and exerts a cell type-specific antiproliferative effect on PT cells. This specificity contrasts with the finding that injected $1,25(\mathrm{OH})_{2} \mathrm{D}_{3}$ inhibits cell proliferation in a variety of cell types, including intestinal mucosa (5). It should be noted, however, that the cell type-specific antiproliferative effect of NPS R-568 is not simply due to CaR-positive or CaR-negative of the cell. The CaR is not only expressed on PT cells, but is also expressed on thyroid C-cells $(34,35)$. These two types of cells, however, show opposite regulation by $\mathrm{Ca}^{2+}{ }_{\mathrm{o}}$ for their hormone release, i.e., suppression for PTH versus stimulation for calcitonin $(10,23)$. It has been proposed that GPCRs might regulate cell proliferation via divergent cascades depending on the types of cells used. For example, p21 ${ }^{\text {ras }}$-dependent MAP kinase is activated by GPCRs through cell type-specific tyrosine kinases, e.g., the epidermal growth factor receptor in Rat-1 fibroblasts (36), Lyn and Syk in avian B cells (37), and Src coupled to Pyk2 in PC12 cells (38). Therefore, it is feasible that the antiproliferative action of NPS R-568 is closely related to growth mechanisms specific to PT cells.

It remains unclear, however, which cascade(s) lie between the CaR and PT cell proliferation. Cyclin D1 was reported to be upregulated at mRNA levels by low concentrations of $\mathrm{Ca}^{2+}{ }_{\mathrm{o}}$ in a rat PT cell line, and possibly to serve as a regulator of $\mathrm{Ca}^{2+}{ }_{\mathrm{o}}$-dependent PT cell proliferation (28). It seems unlikely, however, that cyclin D1 operates directly downstream of the $\mathrm{CaR}$ in rats treated with NPS R-568 because no apparent difference in cyclin D1 expression was observed between NPS R-568-treated and vehicle-treated animals by immunostaining for cyclin D1. This result is in concert with a finding that no overexpression of cyclin D1 was observed in the PT glands of patients with hyperparathyroidism secondary to CRI (4). We are currently investigating the molecular mechanisms involved in CaR-regulated PT cell proliferation.

Our results may be of clinical relevance for intervention in PT hyperplasia. The importance to control PT hyperplasia stems from the findings that very few PT cells undergo apoptotic cell death under physiological conditions and in response to $1,25(\mathrm{OH})_{2} \mathrm{D}_{3}$ treatment or low Pi diet $(2,6,15,21)$. These findings suggest that PT hyperplasia is an irreversible process (6). Consistent with these findings, administration of NPS R-568 did not induce PT cell apoptosis in 5/6 nephrectomized rats. This result accounts for our previous observations that PT hyperplasia was almost completely prevented, but not reversed, by treating $5 / 6$ nephrectomized rats with NPS R-568 by various regimens (unpublished personal data; 39, 40). Therefore, our results suggest that the $\mathrm{CaR}$ is a potential target for prevention of PT hyperplasia.

In summary, we have demonstrated that the calcimimetic compound NPS R-568 inhibits PT cell proliferation in rats with renal insufficiency principally by directly acting on the $\mathrm{CaR}$. The critical piece of human data in relation to this result is that the $\mathrm{CaR}$ is downregulated in hyperplastic PT glands in patients with CRI $(13,14)$. Our results lend support to the hypothesis linking the CaR with PT hyperplasia development. Finally, the results of this study suggest that the CaR is a potentially useful target for therapeutic agents to prevent PT hyperplasia.

\section{Acknowledgments}

The authors would like to thank Hideaki Fukushima, Masaya Nakagawa, Jun-ichi Koumegawa (Kirin Brewery), and Edward F. Nemeth (NPS Pharmaceuticals, Salt Lake City, UT) for supporting the project, John Fox (NPS Pharmaceuticals) for comments and suggestions throughout the experiments and for improving the manuscript, and Yoshiko Kobayashi and Yasuko Kikuchi (Kirin Brewery) for excellent technical assistance.

\section{References}

1. Kronenberg, H.M. 1996. Parathyroid hormone: mechanism of action. In Primer on the Metabolic Bone Diseases And Disorders Of Mineral Metabolism. M.J. Favus, editor. Lippincott-Raven Publishers, Philadelphia. 68-70.

2. Parfitt, A.M. 1994. Parathyroid growth: normal and abnormal. In The parathyroids. J.P. Bilezikian, M.A. Levine and R. Marcus, editors. Raven Press, New York. 373-405.

3. Drüeke, T.B. 1995. The pathogenesis of parathyroid gland hyperplasia in chronic renal failure. Kidney Int. 48:259-272.

4. Tominaga, Y., and H. Takagi. 1996. Molecular genetics of hyperparathyroid disease. Curr. Opin. Nephrol. Hypertens. 5:336-341.

5. Szabo, A., J. Merke, E. Beier, G. Mall, and E. Ritz. 1989. 1,25(OH $)_{2}$ vitamin $\mathrm{D}_{3}$ inhibits parathyroid cell proliferation in experimental uremia. Kidney Int. 35:1049-1056.

6. Naveh-Many, T., R. Rahamimov, N. Livni, and J. Silver. 1995. Parathyroid cell proliferation in normal and chronic renal failure rats: The effects of calcium, phosphate, and vitamin D. J. Clin. Invest. 96:1786-1793.

7. Slatopolsky, E., J. Finch, M. Denda, C. Ritter, M. Zhong, A. Dusso, P.N. MacDonald, and A.J. Brown. 1996. Phosphorus restriction prevents parathyroid gland growth: high phosphorus directly stimulates PTH secretion in vitro. J. Clin. Invest. 97:2534-2540.

8. Albright, F. 1941. The parathyroids: physiology and therapeutics. JAMA(J. Am. Med. Assoc.). 117:527-533.

9. Nemeth, E.F., and A. Scarpa. 1988. Calcium signals and the regulation of parathyroid hormone secretion. In Hormones and Cell Regulation Volume 12. J. Nunez, J.E. Dumont, and E. Carafoli, editors. John Libbey Eurotext Ltd., Paris. 215-225.

10. Brown, E. 1991. Extracellular $\mathrm{Ca}^{2+}$-sensing, regulation of parathyroid cell function, and role of $\mathrm{Ca}^{2+}$ and other ions as extracellular (first) messengers. Physiol. Rev. 71:371-411.

11. Brown, E.M., G. Gamba, D. Riccardi, M. Lombardi, R. Butters, O. Ki- 
for, A. Sun, M.A. Hediger, J. Lytton, and S.C. Hebert. 1993. Cloning and characterization of an extracellular $\mathrm{Ca}^{2+}$-sensing receptor from bovine parathyroid. Nature. 366:575-580.

12. Brown, E.M., M. Pollak, C.E. Seidman, J.G. Seidman, Y.-H.W. Chou, D. Riccardi, and S.C. Hebert. 1995. Calcium-ion-sensing cell-surface receptors. N. Engl. J. Med. 333:234-240.

13. Kifor, O., F.D. Moore, Jr., P. Wang, M. Goldstein, P. Vassilev, I. Kifor, S.C. Hebert, and E.M. Brown. 1996. Reduced immunostaining for the extracellular $\mathrm{Ca}^{2+}$-sensing receptor in primary and uremic secondary hyperparathyroidism. J. Clin. Endocrinol. Metab. 81:1598-1606.

14. Gogusev, J., P. Duchambon, B. Hory, M. Giovannini, Y. Goureau, E. Sarfati, and T.B. Drüeke. 1997. Depressed expression of calcium receptor in parathyroid gland tissue of patients with hyperparathyroidism. Kidney Int. 51: 328-336.

15. Wernerson, A., O. Svensson, and F.P. Reinholt. 1995. Quantitative and three-dimensional aspects of the rat parathyroid gland in Normo-, hypo, and Hypercalcemia. Microsc. Res. Tech. 32:129-147.

16. Raisz, L.G. 1963. Regulation by calcium of parathyroid growth and secretion in vitro. Nature. 197:1115-1116.

17. Brandi, M.L., L.A. Fitzpatrick, H.G. Coon, and G.D. Aurbach. 1986. Bovine parathyroid cells: Cultures maintained for more than 140 population doublings. Proc. Natl. Acad. Sci. USA. 83:1709-1713.

18. Kremer, R., I. Bolivar, D. Goltzman, and G.N. Hendy. 1989. Influence of calcium and 1,25-dihydroxycholecalciferol on proliferation and proto-oncogene expression in primary cultures of bovine parathyroid cells. Endocrinology. 125:935-941.

19. Ishimi, Y., J. Russell, and L.M. Sherwood. 1990. Regulation by calcium and $1,25-(\mathrm{OH})_{2} \mathrm{D}_{3}$ of cell proliferation and function of bovine parathyroid cells in culture. J. Bone Miner. Res. 5:755-760.

20. Wernerson, A., S.M. Widholm, O. Svensson, and F.P. Reinholt. 1991. Parathyroid cell number and size in hypocalcemic young rats. APMIS. 99:10961102.

21. Wernerson, A., O. Svensson, and F.P. Reinholt. 1989. Parathyroid cell number and size in hypercalcemic rats: A stereologic study using modern unbiased estimators. J. Bone Miner. Res. 4:705-713.

22. Nemeth, E.F. 1995. $\mathrm{Ca}^{2+}$ receptor-dependent regulation of cellular functions. NIPS. 10:1-5.

23. Nemeth, E.F. 1996. Calcium receptors as novel drug targets. In Principles of Bone Biology. J.P. Bilezikian, L.G. Raisz, and G.A. Rodan, editors. Academic Press, Inc., San Diego. 1019-1035.

24. Heath, H., III, E.L. Sanguinetti, S. Oglesby, and T.B. Marriott. 1995. Inhibition of human parathyroid hormone secretion in vivo by NPS R-568, a calcimimetic drug that targets the parathyroid cell-surface calcium receptor. Bone. 16 (Suppl 1):85.

25. Silverberg, S.J., S. Thys-Jacobs, F.G. Locker, E.L. Sanguinetti, T.B. Marriott, and J.P. Bilezikian. 1996. The effect of the calcimimetic drug NPS R-568 on parathyroid hormone secretion in primary hyperparathyroidism. J. Bone
Miner. Res. 11 (Suppl 1):116

26. Gavrieli, Y., Y. Sherman, and S.A. Ben-Sasson. 1992. Identification of programmed cell death in situ via specific labeling of nuclear DNA fragmentation. J. Cell Biol. 119:493-501.

27. Gundersen, H.J.G., and E.B. Jensen. 1985. Stereological estimation of the volume-weighted mean volume of arbitrary particles observed on random sections. J. Microsc. (Oxf.). 138:127-142.

28. Bianchi, S., S. Fabiani, M. Muratori, A. Arnold, K. Sakaguchi, T. Miki, and M.L. Brandi. 1994. Calcium modulated the cyclin D1 expression in a rat parathyroid cell line. Biochem. Biophys. Res. Commun. 204:691-700.

29. Talmage, R.V., R.J. Toft, and R. Davis. 1960. Parathyroid activity in nephrectomized rats. Texas Rep. Biol. Med. 18:298-308.

30. Hansson, C.G., S. Mathewson, and K. Norrby. 1971. Parathyroid cell growth and proliferation in nephrectomized rats. Pathol. Europ. 6:313-321.

31. Denda, M., J. Finch, and E. Slatopolsky. 1996. Phosphorus accelerates the development of parathyroid hyperplasia and secondary hyperparathyroidism in rats with renal failure. Am. J. Kidney Dis. 28:596-602.

32. Chattopadhyay, N., A. Mithal, and E.M. Brown. 1996. The calciumsensing receptor: a window into the physiology and pathophysiology of mineral ion metabolism. Endocr. Rev. 17:289-307.

33. Ho, C., D.A.Conner, M.R. Pollak, D.J. Ladd, O. Kifor, H.B. Warren, E.M. Brown, J.G. Seidman, and C.E. Seidman. 1995. A mouse model of human familial hypocalciuric hypercalcemia and neonatal severe hyperparathyroidism. Nat. Genet. 11:389-394.

34. Garrett, J.E., H. Tamir, O. Kifor, R.T. Simin, K.V. Rogers, A. Mithal, R.F. Gagel, and E.M. Brown. 1995. Calcitonin-secreting cells of the thyroid express an extracellular calcium receptor gene. Endocrinology. 136:5202-5211.

35. Freichel, M., A. Zink-Lorenz, A. Holloschi, M. Hafner, V. Flockerzi, and F. Raue. 1996. Expression of a calcium-sensing receptor in a human medullary thyroid carcinoma cell line and its contribution to calcitonin secretion. Endocrinology. 137:3842-3848.

36. Daub, H., F.U. Weiss, C. Wallasch, and A. Ullrich. 1996. Role of transactivation of the EGF receptor in signaling by G-protein-coupled receptors. Nature. 379:557-560.

37. Wan, Y., T. Kurosaki, and X.-Y. Huang. 1996. Tyrosine kinases in activation of the MAP kinase cascade by G-protein-coupled receptors. Nature. 380 $541-544$.

38. Dikic, I., G. Tokiwa, S. Lev, S.A. Courtneidge, and J. Schlessinger. 1996. A role for Pyk2 and Src in linking G-protein-coupled receptors with MAP kinase activation. Nature. 383:547-550.

39. Chin, J., S.C. Miller, E.F. Nemeth, and J. Fox. 1996. The calcimimetic compound NPS R-568 reduces parathyroid cell and gland size but not cell number in rats with chronic renal insufficiency. J. Bone Miner. Res. 11 (Suppl 1):121.

40. Chin, J., R. Conklin, S. Lowe, B. Petty, E.F. Nemeth, and J. Fox. 1996. NPS R-568 inhibits parathyroid cell hyperplasia and hypertrophy in rats with chronic renal insufficiency. J. Am. Soc. Nephrol. 7:1812. 